\title{
Bully Phenomenon toward the Apparance of Violence in Educational Institutions (A Case Study in North Aceh)
}

\author{
Chairan M. Nur ${ }^{1}$ \\ ${ }^{1}$ Lecturer of UIN Ar-Raniri Aceh Indonesia, Jl.Syaikh Abdul Rauf, Kopelma Darussalam Banda Aceh, Indonesia \\ Correspondence: Chairan M. Nur., Lecturer of UIN Ar-Raniri Aceh Indonesia. Jl.Syaikh Abdul Rauf, Kopelma \\ Darussalam Banda Aceh, Indonesia.
}

Received: January 21, 2018

Accepted: February 24, 2018

Online Published: March 20, 2018

doi:10.5539/ass.v14n4p23

URL: https://doi.org/10.5539/ass.v14n4p23

\begin{abstract}
This study aims at determining bully phenomenon among teenagers who bring impacts of violence in educational institutions, and how to eliminate it among teens when the existence of educational institution away from all forms of violence in North Aceh. Qualitative research methodology was used. Data was collected through observation and interview techniques. A descriptive qualitative analysis were used. Data checking was done by triangulation of sources, techniques, and timing.

The results showed that bullying phenomenon among teens had the impact on violence in educational institutions, especially in a school environment where oppression and squash be a familiar sight. Initially, it was only at the level of ridicule, and then it developed into acts of repression, threats, and physical violence. To eliminate these, it should give guidance, advice, examples from the school, and enrich Islamic knowledge agains bullying.
\end{abstract}

Keywords: Bully phenomenon, violence, educational institutions

\section{Introduction}

Currently, violence issues occur surrounding education world in Indonesia. Violence is done not only physically but also psychologically. The tendency to solve the problems is by forcing perceived as the best solution by some of the students as if the self-existence can only be shown by hitting another person, or subjecting opponent by physical fights. Violence is sometimes triggered by a small problem, frequently it makes victim painful until death. Moreover, there are children behaviors who like to insult, mock, or harass their classmates. All of these factors lead to violence in educational institutions.

In the context of education, violence in the school environment can be found in the form of bullying. Rigby (2003, p. 583) says that bullying is a behavior form in which there is coercion or business with the goal of psychological or physical harm against a person or group of people who are 'weak', by more 'robust' person or people. There are so many factors why a person does the bullying. Generally, people bully someone because they feel pressured, threatened, humiliated, revenge and so on. Bullying is caused by the victim environment which makes their personality aggressive and the inability of controlling their emotions, such as home environment, unharmonious family or frequent acts of violence committed by parents to their children who are too restricted or completely banned.

Faeni and Pratomo (2012) state that research shows about $83 \%$ of children doing bullying is a product of a family who also physically or psychological used to live in violence. Meanwhile, Gichara (2008, p. 30) says that that the causes make people be perpetrators of bullying can be from a diverse factors such as because of parents who pampered their children, broken families so the child became excluded, or simply because the child got bullying behavior of group interaction and the effects of violence which are shown on the Internet or television.

\section{Literature Review}

Ghicara (2008) adds that bullying behaviors from time to time continue to haunt the students, and as a threat, both physically and verbally. This is not only happening in big cities but also has spread to various regions. Cases of bullying that is often encountered are the case of seniority or intimidation older students to younger class both physical and mental. Bullying appears everywhere, bullying does not choose the age or sex of the victims, the victims generally are weak children, timid, reserved and 'specials' (disability, closed, clever, pretty, or have a certain body characteristic) that can be the subject of ridicule (Astuty, 2008). 
Bullying is not socially acceptable. The results of some studies revealed that $10-60 \%$ of students in Indonesia reported that it has received derision, ridicule, isolation, beatings, kick, or encouragement, at least once a week (Huneck . In Indonesia, bullying cases in a school ranked as the top public complaints to the Indonesian Child Protection Commission (KPAI = Komisi Perlindungan Anak Indonesia) in the education sector. From 2011 until August 2014, KPAI recorded 369 complaints related to the problem. The amount is about $25 \%$ of the total complaints in the field of education as many as 1,480 cases. Bullying called KPAI as a form of violence in the school beat student brawls, educational discrimination, complaints or extortion (Halimah et al.).

The high rates of violence in Aceh, especially for elementary school level (SD) and High School (SMP), is a sad fact that actually can be prevented. The latest reported incident in Serambi Indonesia on one junior high school students in the region of the town of Lhokseumawe, beaten her friend to be injured and hospitalized. The incident started when the victim asked the teacher to share the paper with his friends, then one of the students held the child's shoulder, which led to the quarrel mouth. This event continued until the time of learning is completed. Beatings happened outside the classroom involving other children as friends' perpetrators, which makes the victim seriously injured.

This tragic story should not have happened at school that teaches children to be polite, behave well and educates the children to have a strong mentality becomes not a quitter. The influence of television or bias education accessible at home or in the community have made many children into acting like playfulness. Mocking a friend or excessive joking, of course, makes one does not accept the gesture. Though the teachings of Islam strictly forbid someone mocked or insulted another person. However, now the condition is actually rife exhibited in the education world that should educate children to have a good personality.

The cases occurred in the school really very educational for the younger generation in the future. Sekolahmerupakan socialization agent after the family where a child begins to learn the new values are not learned in the family. The school is a means to prepare a child to confront its role in society. If you see phenomena that occur, it looks like the school began to fail to perform its functions.

During bullying tend to be ignored or overlooked in everyday life. There are still many who think that bullying is not dangerous, but this action could negatively impact victims. Bullying can be done physically, by use of force, verbal bullying is done by cursing, insulting, defamatory, embarrassing in public, slander and so forth, psychological bullying is to intimidate, threaten, isolate, humiliate, pout and so forth (Adilla, 2009).

Stephenson and Smith in Trevi (2012) identified three types of bullies, among others: 1) Actors who believe themselves where the offender has a strong physique, like aggression or violence, and have always felt safe popularity; 2) Actors who are worry where the actors feel weak in their academic value, low concentration, less well-known and also less safe (there are $18 \%$ of the perpetrators and mostly male), and 3) Perpetrators who target victims and in certain situations also been in "bullied" by others. Education is one of the elements of human needs that have benefits to improve people life and was instrumental in shaping human behavior according to the normative (good or bad). With the creation of a good education, it is hoped will emerge the next generation of qualified and able to adapt to living in a society, nation, and state.

This research centered in North Aceh by referring to the existence of some cases of violence triggered by bully factors. As a rapidly growing area with a heterogeneous community life, and receptive to a foreign culture, the phenomenon of bullying can easily occur in this area. Bullying behavior of others can easily found in various television shows and movies as well as youtube, where the children so easily can access such behaviors.

Bullying can leave a devastating effect on individuals and can affect every aspect of life which are not directly related. For that Wharton (2009), sparked a high vibration method to overcome this problem. High vibration method is a new concept that complements the knowledge of the movement of energy in the universe. This concept offers a way of looking at a person, and the interaction between people, as part of the process of transmission of energy that can be very empowering individuals. By promoting a positive outlook toward others, there will be mutual respect of love each other, and keep someone from mutual hate.

Bully is a very scary phenomenon of violence, like a bully nonverbal violence, but when the victim can not fight back directly, then certainly it arises a sense of revenge in the victim which can lead to physical violence. Violence in any form can not be tolerated, let alone hit the people who are weak, for example, disabled, poor or marginalized people.

Educational institutions have an obligation to educate students to be noble human, being smart intellectually, emotionally and spiritually. However, if in the process of education occurs an atmosphere of mutual insult, ridicule, and cornering peers, efforts to educate children would be absurd. Then the school and all the elements 
that are inside should be able to create a comfortable atmosphere, quiet, mutual respect among pupils; and between students and teachers.

\section{Research Methodology}

The approach used in the study are using qualitative approaches. This study conducted in two junior schools in North Aceh. Both of the schools located in urban areas and rural areas. The reason the choice of location is based on preliminary data is published by the news media and the information from the teacher on duty in the town of Lhokseumawe, that there were cases of bullying in the region, the which should be investigated seriously. In this study, the process of data collection techniques using multiple data collection items, namely: In-depth Interviews, Focus Group Discussion (FGD), questionnaires, and study of the documents

Overall, the data had been collected and obtained in a variety of techniques of data collection before being analyzed using several categories and stages. Data generated from the interviews then analyzed through the stages of editing, reduction, and data presentation. The information that was widely accepted in the interview edited and reduced to collect data relating to the central theme of this research. This process was further narrated that will then be compiled in the form of a research report. In addition, data of questionnaire was analyzed through the editing process to check the completeness of all the data that has been collected clarity of writing, ideas, consistency and uniformity. The intent of this editing process was to get the valid data, in order to minimize errors and doubts in interpretation.

\section{Results and Discussion}

\section{Historicity \& Phenomenon Bullying}

Recently, violence cases in school are more often encountered toward information in the mass media and virtual. Besides, actually there are forms of aggressive behavior or cruelty that may have happened in schools for a long time, but there is no fully attention, or even be considered seriously by many parties, such as stakeholders, or society. For instance, intimidation from friends or bullying, ostracism, that make children become indolent to go to school since they feel threatened dan scared, so it could be mild depression stage and affect their study at school.

In the context of education, violence in the school environment or educational institution can be found in the form of bullying. Bullying is a behavior form of coercion or where there is a business with the intention of hurting the psychological or physical against any person or group of people who are more 'feeble', by a person/group of people who are more 'strong' (Rigby, 2003). The term bullying refers to aggressive behavior were made repeatedly by a person or group of students who have the power to the student or other students who are weaker, with the aim of hurting the person. Based on these definitions, it can be concluded that bullying behavior has actually been very widespread in the world of education unconsciously without thinking the consequences. It had long been familiar with the term hazing education, squashing, bullying, intimidation, and so forth. The largest percentage of bullying are in the neighborhood elementary school and junior high school. Olweus (2005), also states that bullying behavior is evident even in preschool and the problem peaks in middle school.

Bullying is a behavior that has long been underway and threatens all aspects of life for most of the children within the home, school and in society. The history of bullying begins even hundreds of thousands of years ago when the Neanderthal man was replaced by Homo Sapiens stronger and more developed. The main theme of the recorded histories regarding bullying behavior is the exploitation of the weak by the strong, not by accident but purposive or aims. Bullying appears in different forms, among other forms of non-physical such as derision and ridicule, but it also can appear as physical action. "Bullying is part of the failure to build a comprehensive intelligence" (Statement Education Minister Bambang Sudibyo in Bullying Seminar: The Hidden Problems in Education in Indonesia, in Jakarta, 29 April 2006 quoted by the Kompas daily, May 1, 2006).

Cases of bullying in children are like an iceberg phenomena, the case is sticking looks like not a big problem, but in fact, it emerges everywhere, rooted, inherited and often captivate the generations who are less monitored by parents and schools. Some parents and school see that bullying only occurs in junior high, and senior high school. Nevertheless, in fact, many of them occur in children from age range 3-12 years. At this age, cases of bullying have received less attention, because it regarded as a natural thing.

Bully has become the worldwide phenomenon, and the influence and associated information can be received by anyone who accesses the virtual world. Based on the case in North Aceh, children will imitate the bad behavior and apply to other people around them. Bully occurs in children who are weaker than those who do bully. If there are children in the class who were very dominating and stubborn then, they felt more powerful than others 
or supported by family power make them very easy to perform bully to others.

"Parents and teachers must take seriously the young protege if there is the phenomenon of bullying, firm action must be taken immediately. Children should be reminded that the bad deeds that must be shunned. Teachers also need to open communication with students, dare to tell if there is a bully in their class. Without fear or revenge, a child must dare to convey when he was insulted, mocked or feared. If no adult who knows the incident, it will be easy for the child who feels they have the power to disrupt the weak." (Interview with Ms. Wali (teacher)).

\section{The Trigger of Bullying Emergence}

Interview with one of the students in North Aceh School, said that the bullying behavior in their school happened in marginal classes. He added that for the weak student but he has a high intelligence, they are usually bullied by mocking in the case for having fun, but the actor (impertinent students) did not plague them physically and mentally. This kind of verbal bullying is used to be done by more than one student. Initially, it started by a person then followed by the others to do the similar deeds of bullying. Based on his statement, it can be supposed that there were some cases which were unnoticed and isolated. That such alienation may occur more opportunities for bullying acts. Initially, it may just be kidding, but when this continues, then this would be a bad habit among the students.

Children sometimes play each other, or fight as part of entertainment in play and socialize. However, this condition is often uncontrolled and skipped parents' attention, teachers' monitoring and even by people around. Most teachers and parents think that bullying by children is just a small problem and does not have a negative impact. In fact, things like that gradually get worse and can cause adverse effects. Bully in a mocking connotation is still considered unusual by people around the school or in the household. It is considered harmless, for instance, in the classroom, the children's ridicule sometimes left by his teacher. Yet, this is dangerous if it is not immediately stopped by a teacher or parent.

There are a few things to be possible causes of bullying. Quiroz et. al. (2006) state three factors that can lead to bullying behavior, as follows:

\section{Peer and Social Environment Factors}

There are several causes of bullying act, namely: (1) anxiety and feelings of inferiority from a perpetrator. (2) unrealistic competition, (3) A person who had been hurt or bullied usually keeps resentment that wants to be distributed to others so that other feel the same way, one of them is doing the bullying because of the perpetrator bullying had been as the victim of bullying previously, (4) hostility and resentment among friends which leads a person to perform acts of bullying, and (5) the inability to handle emotions positively.

\section{Family Relationships}

Children will imitate the values and behavior of family members who visit daily to become espoused values and behaviors (the result of imitation). If the child is raised in families that tolerate with violence or bullying, the children will learn that bullying is a behavior that is acceptable in building a relationship or in achieving what they want (image), so that later on, the child imitate bullying behavior. According to Priyatna (2010), it is because of the type of parents at home who likes swearing, comparing or doing physical violence. Children also consider the true language of violence. If we trace from the family, someone who develops aggressive behavior grows in the care that is not conducive; then children experience attachment that is not safe with immediate caregivers, parental discipline is too harsh or too loose, and psychological problems are commonly found in the elderly; spousal conflicts, depression, antisocial, and violence on family members.

\section{Less Confident and Looking for Attention}

Someone who has lack confidence needs others' attention, one of the ways to choose is by doing the bullying. Bully others will make him feel satisfied, more powerful and dominant. Feeling of wanting to be considered to be the most crucial thing traps people to bully. When he did bully then all eyes are on him. It was expected by a child, to draw attention to it.

As happened in SMP Negeri 2 Lhokseumawe, a student who does not stand out in terms of achievement, not well known to the teacher, he became the darling of the teachers. Bully action taken is in the form of verbal, such as taunting, laughing, even excommunicating. Perpetrators often tell bad things about the victim in more friends and invite them to participate hostile to victims. It can be seen that the way to get the attention of the students and cover up the fact that the victim was on top of it or superior to it, both in achievement and popularity.

\section{Negative Effects of Media}

Increasing number of media images of violence on both television, internet, and so on. A bad example that could 
inspire someone to commit violence without clear reason. Survey conducted by Kompas showed that $56.9 \%$ of children mimicking scenes that had been seen in the movie, they generally mimic the movement $(64 \%)$ and words (43\%),

This makes verbal bullying is considered normal and reasonable because that was shown during this sort of civilizing act of bullying. In Indonesia, many TV shows apply it, especially which contain elements of comedy, hurling taunts, profanity, just for the tummy tickle the audience.

As presented by a student, he said that mostly bullying happening in their schools was limited to verbal only, and still within the joke. Even the target is not too questioned because it considers only your pleasure, amusing, and simply happened in school.

Another student from of SMP Negeri 2 Cot Girek also provided a statement that bullying happened in their schools largely remains in reasonable stages, and it is still regarded as part of the association, not to harm the victim physically as hurl taunts, ridicule, and mocking. To ridicule themselves, the perpetrators used the name of victims parents' name as their bullying.

Perpetrators Categories and Victims of Bullying

Stephenson and Smith (in Trevi, 2010) identified three types of bullies, among others: (a). Perpetrators are confident where the person does bully has a strong physique, like aggressive or violence, always felt safe and having popularity; (b). Actors who were the worry when they are weak in academic values has low concentration, less well-known and also less safe (there are $18 \%$ of the perpetrators and they are mostly male). (c). Perpetrators who target specific victims and in this situation, they also been in "bullied" by others.

The high rates of violence in Aceh, especially involving children elementary school level (SD) and High School (SMP), is a sad fact that actually can be prevented. The latest reported incident Serambi Indonesia on one junior high school students in the region of the town of Lhokseumawe, beaten her to be injured and hospitalized. The incident started when the victim asked the teacher to share the paper with his friend, then one of the students hold his shoulder which led to the quarrel. This event continued until the class ended. Beatings happened outside the classroom involving other children as perpetrators' friends which made the victim seriously injured.

Depth Bullying

Bully in the lightest category is at the verbal level. At this level, the bully usually did in the form of mockery, ridicule, invective. Usually, what often happens is a friend pinned title to another friend with designations pertaining to the physical, such as ugly, fat, short, etc., committed with intent to joke as a laughing stock together his friends. Moreover, the behavior marginalized someone with gossip and backbite also included in the bully on the verbal level. Verbal abuse like this, if continually allowed to happen, then it will lead to a negative impact, particularly on the mental victim. One of the effects of verbal violence experienced by a child is a loss of confidence. That is because a child is constantly assaulted with insults, taunts, and inappropriate word that was brought to him. Eventually, this will lead to fear in a child, the loss of confidence and loss of ability to act.

Verbal violence is often underestimated, but because its effects are not seen physically, those who do so were often not conscious of having committed verbal abuse. People do verbal bullying with the intention of jokes material in daily life in a school environment, so they never think about the consequences or impacts that would be acceptable casualties. In fact, verbal violence may adversely affect greatly to the psychological development of a child.

For the highest type, the bully does is in the form of physical violence. Physical bully is all forms of bully that takes the form of harassment and physical violence. For instances, hitting, grabbing, pushing, scratching, spitting, biting, kicking, slapping, damaging or destroying the victim by intention.

As the incident happened in SMP in North-Aceh, based on an interview, a friend who often deliberately hit and grabbed his friend, became his act as a bully because the offender was unhappy and jealous of the victim who is physically and accomplishments ahead of him. His friend (victim) always be a favorite and got teachers' attention. He then channeled resentment and dislike for the victim to physically hurt her.

Although physical bullying category is the most visible category and easy to identify, but the incidence of physical bullying is not as much of another bullying categories such as verbal bully. Teenagers who regularly and continuously in the form of physical bullying is most troubled teens and tend to turn to the further criminal acts.

Psychological Effect Against Bullying

A student then told about his old female friend, who is tiny, silent, and often became the butt of her friends. She showed her displeasure but she was unable to do anything. So, she only did when bullied is crying. Due to the 
frequent treated the way, the victim so often and easy to cry when there were things bothered and offended her. Another case happened to a male student at SMP Negeri 1 Lhoksukon, bully increasingly made him difficult to get along. He became more introvert, closed and discomfort at school. People thought he did not want to be friends, but this time he was depressed because of ill-treatment in the long time period. His friend said that so far there has no act of bullying in the level of physical violence, only at the verbal level. However, when the victim mockery felt offended and no longer regarded it as a joke, then she will report it to the teacher.

Viewed from the cases above, the most visible impact is the reduced of psychological well-being and poor social adjustment. It is a disorder that may be less visible but result in long-term effect (Levianti, 2008). Victims will usually feel negative emotions such as anger, resentment, depression, fear, shame, sad, uncomfortable, threatened, but not powerless. In the long term, this condition can develop feelings of inferiority and worthlessness. Consequently, there are a lot of students who want to get out and move to another school. If they still survive there, they usually have impaired concentration and get low achievement in learning performance or they often deliberately absent from school.

The recent case, there was the murder of a 9-year old child by his friend, who was 13 years old. The killing was motivated by emotional stress perpetrators of the murder words that seem to harass his friends. This case is in Bener Meriah district. Two playmates are close friends, until one day, one was killed by his own friend (the 13-year-old boy). The story begins when the perpetrator invited his friend to go to the woods to look for bamboo as a tool for making toys. The perpetrator carried a machete in his hand. When he got to the woods, victim's hand was nudged with the perpetrator's machete, so that it caused injury. There was blood coming out in the wound, and when the perpetrator was attempting to treat the wound, the victim said, "do not cry! do not be a crybaby like a child". The words seemed to mock the cause of hatred and resentment of the offender. Furthermore, the perpetrators turned around and directed his machete at the victim. With a few punctures, the victim fell and died.

Above case reflected one of the bullying causes, which is when a child fails, he is not able to handle emotions positively. By unstable emotions, the child is not able to stem the anger that enveloped, consequently, emotion, anger, and the offense became a negative act, with terrible consequences, namely the killing other.

The sustainability of bullying actually depends on how the response was given when looking at these events, especially their peers and how the treatment is given, especially by the school. Bully ingrained habit requires the involvement of all parties to stop it. The most ideal are there are policies and integrated actions that involve all components ranging from teachers, students, principals, to parents, which aims to stop bullying behavior and ensure safety for victims.

Sullivan (2000, in Trevi, 2010) states that bullying is very dependent on the people around who engage in it are often referred to as an observer or watcher who did not do anything to stop the bullying or being actively involved in supporting bullying. According to Coloroso (in Trevi, 2010), there are four factors that often reasonably felt bystander not doing anything, they are (a) bystander is fear of injuring himself, (b) bystander is afraid that $\mathrm{s} / \mathrm{he}$ will become a new target by the perpetrator, (c) bystander is afraid if $\mathrm{s} / \mathrm{he}$ does anything, it will exacerbate the situation and (d) bystander do not know what to do.

Handling from the school, based on the interview, concludes that there have been several reports of bullying which are up to it, and it was obtained directly from the victim's parents. One of them, which turned out not stand because it continues to be a bully victim of her friends for a long time, it gets complained from parents and asks to be moved from the school. Based on the complaint of the child, bullying during the time he received is not only verbally but also physically. Students are often as the target of ridicule of his friends, and also often take a hit in the head. A teacher who received the report immediately took action by visiting students who became actors and tried to resolve the problem by reducing the bullying acts, as well as making both victims and perpetrators peace.

Some reflection, preventing, and shortcoming acts have been done by the school so that it is hoped that the cases do not happen again. For instance, the principle said that SMP Negeri 1 Lhoksukon has been fostering for a full month to students who has lack capabilities in terms of academic and for students who require special attention and then should be given guidance about the characters to be those who are more eager to learn and have an increase in terms of morals. In addition to development activities which carried out by teachers at SMP Negeri 1 Lhoksukon, it is added by providing reinforcement in the area of religion and learning about building character and morals as an exemplary student in every hour lesson.

Suppose as happened at one of the schools in Banda Aceh, Based on the story of alumnus in the school of Banda Aceh, a lot of bullying are still going on in schools. The oppression that occurred as if it had become a habit that 
is fair, has become the everyday student get in the school environment. Sometimes, it because of having a family background that makes some children become proud, arrogant and do not have fear and respect for others. Bullying happens even occurs not only between the student and the student but also could be among teacher and the students themselves. Heartbreaking is when the schools do not do anything or unable to do anything to follow up the incident, especially for events that occur between students bullying. Since in the neighborhood, it had already become a daily sight.

A great website in Indonesia that gives great attention to the prevention of bullying practices in the world of education, namely "Sudah Dong! Stop-Bullying Campaign, states that during this time, there are many teachers who do not notice what is happening among his students. It is important that teachers have the knowledge and skills about prevention and how to cope with school bullying. Moreover, the curriculum should contain elements of the development of pro-social attitudes and teachers provide reinforcement to the application in everyday life at school. Schools should support activity groups to be attended by all students. Furthermore, schools provide access to a complaint or a forum for dialogue between students and schools, or parents and schools, and build school rules and clear sanctions against bullying.

\section{Conclusion}

The phenomenon of bullying among adolescents has an impact on violence in educational institutions, especially in the school environment in which suppression and squashing be a familiar sight. Initially, it is only at the level of ridicule, to develop into acts of repression, threats, moreover to physical violence. It makes this phenomenon more heartbreaking when a lot of events in the school bully left alone without any further handling or actions that should be taken so that these events do not reoccur. In order to eliminate the phenomenon of bullying among teenagers, for the existence of the education agency away from any form of violence is to give guidance, and deepen the integration of Islamic values to against bully behavior.

\section{References}

Adilla, N. (2009). The Influence of Social Controls on Bullying Behavior of Junior High School Students. Journal of Criminology IndonesiaUniversitas Indonesia, 5(1), 56-66.

Astuty, P. R. (2008). Reducing Bullying: 3 Ways To Effectively Overcome Violence In Children. Jakarta: Grasindo.

Faeni, D. P., \& Pratomo, D. Y. (2012). HypnoParenting: Smart Parents Great Kids. Jakarta: Mizan Publika.

Gichara, J. (2008). Overcoming Bad Behavior Anak. Depok: Friends of Pustaka.

Levianti. (2008). Conformity and Bullying At Students. Journal of Psychology, 6(1), 1-9.

Olweus, D. (2005). A useful evaluation design, and the effects of the Olweus Bullying Prevention Program. Psychology, Crime \& Law, 11, 389-390. https://doi.org/10.1080/10683160500255471

Priyatna, A. (2010). Let's End Bullying: Understanding, Preventing and Overcoming Bullying. Jakarta: Elex Media Komputindo.

Quiroz, H., Arnette, J., \& Stephens, R. (2006). Bullying in schools: Fighting the bullying battle. Retrieved from http://www.schoolsafety.us/pubfiles/bullying_facts_sheets.pdf

Rigby, Ken. (2003). Stop the Bullying: A Handbook for Schools. Australia: Australian Council for Educational Research Ltd.

Trevi, W. S. R. (2012). Attitude Student Class X Smk Y Tangerang Against Bullying. Journal of Psychology, 10(1), 14-26.

Wharton, S. (2009). How to Stop That Bully: Stop the Tailor Terror. On. Ratri Sunar Astuti. Yogyakarta: Kanisius.

\section{Copyrights}

Copyright for this article is retained by the author(s), with first publication rights granted to the journal.

This is an open-access article distributed under the terms and conditions of the Creative Commons Attribution license (http://creativecommons.org/licenses/by/4.0/). 